\title{
New Disease Reports \\ Phytophthora siskiyouensis causing stem lesions and cankers on Alnus incana
}

\author{
A. Perez-Sierra*, M. Kalantarzadeh, S. Sancisi-Frey and C.M. Brasier \\ Forest Research, Alice Holt Lodge, Farnham, Surrey, GU10 4LH, UK \\ *E-mail: ana.perez-sierra@forestry.gsi.gov.uk
}

Received: 26 Jan 2015. Published: 18 Apr 2015. Keywords: grey alder, bleeding lesions, cankers, pathogenicity

In late summer 2013, stem cankers and sparse foliage were reported on European grey alder (Alnus incana) growing on a 500 ha site recentlyplanted with broadleaf and coniferous trees in south-west England. A site visit showed that approximately $10 \%$ of more than 1000 grey alders (thought to have been imported from Europe and planted in the late 1990s) had symptoms including bleeding stem lesions similar to those caused by Phytophthora alni (Gibbs et al., 2003). In November 2013, samples were collected from stem lesions (Fig. 1), roots (internal lesions tracking-down from stem lesions) and rhizosphere soil from symptom-bearing trees. Tissue from root and stem lesion margins was plated onto Phytophthora selective medium (SMA) (amended as per Brasier et al., 2005) and incubated at $20^{\circ} \mathrm{C}$ for $48 \mathrm{hrs}$. Green apples were used as baits for soil samples by inserting a few grams of soil under a flap cut in the side of the apple and incubating for $4-7$ days at $20^{\circ} \mathrm{C}$. Isolation from developing SMA mycelial cultures and incubated apple baits onto potato dextrose agar (PDA) and carrot agar (CA) was then undertaken.

After 14 days on PDA at $20^{\circ} \mathrm{C}$ in the dark, colonies exhibited a distinctive stellate growth pattern (Fig. 2a). On CA they had a diffuse 'frosty' appearance (Fig. 2b). On CA, oogonia with predominantly paragynous antheridia and aplerotic oospores were abundant. Partially-caducous sporangia formed when plugs from colonies on CA were submerged in unsterile pond water held at $20^{\circ} \mathrm{C}$ in the dark. Sporangia (46-51 $\mu \mathrm{m}$ wide) were semi-papillate and were ovoid, reniform, elongated or irregular in shape (Fig. 3). Sporangial morphology and dimensions corresponded to Phytophthora siskiyouensis (Reeser et al., 2007) and sequences of ITS and coxII regions supported this identification (GenBank Accession Nos. KP207601 and KP207602).

One isolate of $P$. siskiyouensis was obtained from each of three different symptomatic trees; one from a root lesion, one from a stem lesion and one from associated soil. Koch's postulates were tested by inoculating two-yearold potted A. incana saplings with the three isolates. A small wound was made on the stem $10 \mathrm{~cm}$ above soil level. A CA plug colonised by $P$. siskiyouensis was inserted and the wound was sealed with Parafilm. Nine saplings were inoculated per isolate and maintained at $20^{\circ} \mathrm{C}$ with a $12-\mathrm{hr}-$ photoperiod. Three control saplings were inoculated with sterile CA plugs. After 20 days, cankers and bleeding were visible externally on all of the trees inoculated with P. siskiyouensis (Fig. 4). The bark was peeled away to reveal phloem lesions extending approximately $2-4 \mathrm{~cm}$ above and below the inoculation point. No lesions developed on control trees. After re-isolation onto SMA, a Phytophthora sp. was recovered from all of the inoculated trees but not from the controls and it was identified as $P$. siskiyouensis by morphology (Reeser et al., 2007) and sequencing of the ITS region.

Phytophthora siskiyouensis is a recently-described species in the USA, isolated from stem lesions on myrtlewood (Umbellularia californica) and tanoak (Lithocarpus densiflorus; synonym of Nothocarpus densiflorus) and from soil and stream water, in south-west Oregon (Reeser et al., 2007). It has also been reported causing stem lesions on Italian alder (Alnus cordata) in California (Rooney-Latham et al., 2007). This is the first report of $P$. siskiyouensis in the UK and, to our knowledge, in Europe, and the first report of $P$. siskiyouensis causing stem cankers on A. incana. Its occurrence within a recently-planted site suggests a possible origin on introduced nursery stock. $P$. siskiyouensis has the potential to cause further damage to Alnus spp. and other plant species in Europe. Its comparative pathogenicity on various alder species is under investigation.

\section{Acknowledgements}

The authors would like to thank M. Biddle and B. Wylder for field support and the site owner who has supported us during our work. The Forestry Commission funded the study.

\section{References}

Brasier CM, Beales PA, Kirk SA, Denman S, Rose J, 2005. Phytophthora kernoviae sp. nov., an invasive pathogen causing bleeding stem lesions on forest trees and foliar necrosis of ornamentals in Britain. Mycological Research 109, 853-859. http://dx.doi.org/10.1017/S0953756205003357

Gibbs J, van Dijk C, Webber J, eds. 2003. Phytophthora disease of alder in Europe. Forestry Commission Bulletin 126. Edinburgh, UK: Forestry Commission.

Reeser PW, Hansen EM, Sutton W, 2007. Phytophthora siskiyouensis, a new species from soil, water, myrtlewood (Umbellularia californica) and tanoak (Lithocarpus densiflorus) in south-western Oregon. Mycologia 99, 639-643.

Rooney-Latham S, Blomquist CL, Pastalka T, Costello LR, 2007. First report of Phytophthora siskiyouensis causing disease on Italian alder in Foster City, California. 2007 APS Annual Meeting. Phytopathology 97, S101. http://apsjournals.apsnet.org/doi/pdf/10.1094/PHYTO.2007.97.7.S1

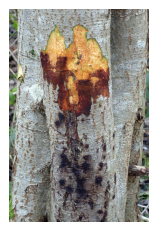

Figure 1

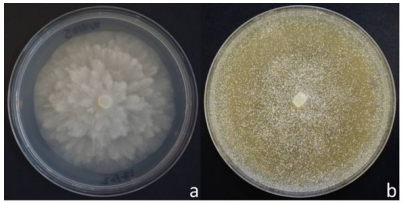

Figure 2

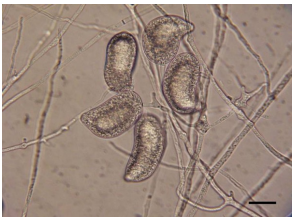

Figure 3

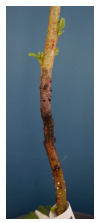

Figure 4

To cite this report: Perez-Sierra A, Kalantarzadeh M, Sancisi-Frey S, Brasier CM, 2015. Phytophthora siskiyouensis causing stem lesions and cankers on Alnus incana. New Disease Reports 31, 17. http://dx.doi.org/10.5197/j.2044-0588.2015.031.017

(c) 2015 The Authors

This report was published on-line at www.ndrs.org.uk where high quality versions of the figures can be found. 